УДК 378.4 (477.46) УДПУ«1946-1954»

DOI: https://doi.org/10.33782/eminak2019.4(28).345

\title{
НАУКОВО-ПЕДАГОГІЧНІ КАДРИ УМАНСЬКОГО УЧИТЕЛЬСЬКОГО ІНСТИТУТУ У ПІСЛЯВОЄННІ РОКИ (1946-1954 РР.)
}

\author{
Олена Джагунова \\ Уманський державний педагогічний університет імені Павла Тичини (Умань, Україна) \\ e-mail: olenadj_111@ukr.net \\ ORCID: https://orcid.org/0000-0003-2129-9761
}

У статті показано процес відновлення, розвитку та діяльності Уманського державного учительського інституту після Другої світової війни. Показано стан забезпечення вищого навчального закладу викладацькими кадрами та ставлення до них держави у повоєнний період. Досліджено та проаналізовано динаміку кількісних і якісних характеристик науково-педагогічних кадрів, їх гендерні, національні та партійні особливості.

Ключові слова: Уманський державний учительський інститут, науковопедагогічний склад, педагогічна освіта, повоєнний період

Радянські науковці розглядали питання історії освіти України, іï повоєнне відродження у контексті загальних процесів у вузах СРСР.У роботах радянських дослідників, присвячених проблемам розвитку радянської вищої школи, питання української вищої освіти розглядалися фрагментарно, не було визначено особливостей розвитку української вищої та шкільної освіти, його специфічних рис. Після проголошення незалежності вітчизняні дослідники звернулись до вивчення історичного досвіду та традицій освіти України. Проблеми повоєнного відновлення освіти України сформульовані у статті Б. Чижевського ${ }^{1}$, Т. Васильчука², В. Мічуди ${ }^{3}$ та Н. Процишин ${ }^{4}$. Також у науковому обігу представлені наукові праці та статті більш локального характеру, які стосуються відновлення та діяльності окремих вищих навчальних закладів у згаданий період.

Однак період повоєнної відбудови навчальних закладів різного рівня в Україні ще недостатньо досліджений істориками. Мало приділялося уваги повоєнному відновленню педагогічної вищої освіти, яка $є$ вагомою складовою підготовки висококваліфікованих спеціалістів 5 .

Розвиток вищої педагогічної освіти у післявоєнний період представлений широким колом джерельних матеріалів. У фондах Центрального державного архіву вищих органів влади та управління України зберігаються документи, які висвітлюють як діяльність вузів, так і Міністерства освіти УРСР. Ще одним джерелом інформації, більш локального значення, виступають обласні держані архіви.

Що ж стосується відновлення та діяльності Уманського державного учительсько-

\footnotetext{
1 Чижевський Б. Освіта у післявоєнні роки // Освіта України. 2003. 24 червня.

2 Васильчук Т. Відновлення вищої педагогічної освіти Української РСР після Великої вітчизняної війни // Наукові праці історичного факультету ЗДУ. 2003. Вип. XVI . С. 245-250.

3 Мічуда В. Радянська система освіти у повоєнний період (1945-1950 роки) // Молодий вчений. 2016. № 12.1. С. 267-271.

4 Процишин Н. Динаміка кількісного та якісного кадрового забезпечення педагогічних інститутів України 1945-1950 років // Обрії. 2013. № 2. С. 23-24.

5 Васильчук Т. Відновлення вищої педагогічної освіти Української РСР після Великої вітчизняної війни // Наукові праці історичного факультету ЗДУ. 2003. Вип. XVI. С. 245.
} 
го інституту у післявоєнний період, то така інформація є лише у статистичних даних окремих загальних праць відповідної тематики та періодуб. Решту можна знайти лише у згаданих вище фондах архівів та в архівах Уманського державного педагогічного університету імені Павла Тичини та Музею історії цього ж університету.

У період сучасних трансформацій і реформування вищої освіти в Україні, особливо актуальним $є$ дослідження різних складників історичного процесу, що стосуються даної проблеми. Уваги заслуговує питання відновлення та реформування освіти після Другої світової війни. Дуже важливо дослідити, яким чином вирішувалася проблема поповнення науково-педагогічного складу вищих навчальних закладів. У тій важкій економічній ситуації питання відбудови діяльності навчальних закладів прирівнювалося до стратегічних завдань .

Важливого значення набула у ці роки проблема забезпечення шкіл педагогічними кадрами. За роки війни Україна втратила 27,5\% складу вчителів, що на 13,5\% перевищує аналогічний показник втрат по СРСР. Хоча після закінчення війни до шкіл повернулося багато демобілізованих педагогів - колишніх солдат і офіцерів Радянської Армії, а також чимало вчителів, що перебували в евакуації, це питання все ж таки привертало постійну увагу. Конкретну програму заходів з удосконалення роботи педагогічних вузів було визначено у постанові РНК СРСР від 20 серпня 1946 р. «Про поліпшення справи підготовки вчителів»8.

У період післявоєнної п'ятирічки (1945-1950рр.) у системі вищої освіти відбулися істотні зміни. Розширилася мережа вищих навчальних закладів, спостерігалася позитивна кількісна та якісна динаміка науково-педагогічних кадрів. Одночасно із післявоєнною нормалізацією навчального процесу в країні розпочалося відновлення інфраструктури вищих навчальних закладів, зокрема, педагогічних. У результаті чого постала проблема відновлення науково-педагогічного та викладацького складу. Забезпечення кадрами ускладнювалося тим, що під час війни значна частина науково-педагогічних кадрів перебувала або у складі Радянської Армії, або ж в евакуації. Крім того, на думку деяких дослідників, процес повернення професорськовикладацького складу до ВНЗ на довоєнні місця роботи не був належним чином організований і проходив у складних умовах розрухи 9 .

Однак, незважаючи на складну ситуацію, Наркомат освіти УРСР відновив діяльність системи вищої педагогічної освіти у країні. Згідно з наказом наркома освіти П.Г. Тичини відновили свою роботу Чернівецький державний університет та учительський інститут, Вінницький педагогічний інститут, Кременчуцький учительський інститут, Уманський державний учительський інститут та ін.10.

\footnotetext{
${ }^{6}$ Майборода В.К. Вища педагогічна освіта в Україні: історія, досвід, уроки (1917-1985 рр.). Київ: Либідь, 1992. 196 с.; Лук'яненко О.В. «Найближчі друзі партії»: колективи педагогічних вишів України в образах щодення 1920-х - першої половини 1960-х років: Монографія. Полтава: Видавництво «Сімон», 2019. 658 с.

7 Мічуда В. Радянська система освіти у повоєнний період (1945-1950 роки) // Молодий вчений. 2016. № 12.1. C. 267.

8 Ibid. C. 270.

9 Процишин Н. Динаміка кількісного та якісного кадрового забезпечення педагогічних інститутів України 1945-1950 років // Обрії. 2013. № 2. С. 23-24.

10 Зуляк I. Наукова й навчально-виховна діяльність Кременецького учительського інституту в 1940-х pp. (на основі архівних матеріалів) // Волинь і волиняни у Другій світовій війні: збірник наукових праць (за матеріалами V Міжнародної науково-практичної конференції, присвяченої подіям Другої світової війни на території Волинської області) / упоряд. М.М. Кучерепа. Луцьк: Волин. нац. ун-т ім. Лесі Українки, 2012. С. 199.
} 
15 червня 1944 р. на обох факультетах ВН3 в Умані (фізико-математичному та природничо-географічному) було урочисто відзначено день початку навчання. Його відзначили 18 викладачів ${ }^{11}$. У 1945 р. викладачів було уже 27, проте ще не вистачало фахівців з фізики та фізруків. В інституті працював лише один кандидат наук, доцент та один кандидат наук без вченого звання, а старших викладачів - 12, викладачів -8 , асистентів - 5 чоловік ${ }^{12}$. Хоча, у період відновлення навчального закладу, відомостей про кількість кафедр та їх назв немає, можна зробити припущення про існування відповідних кафедр із наявної інформації про діяльність дев'яти навчальнонаукових кабінетів: основ марксизму-ленінізму, фізкультурної підготовки, математики, фізики, ботаніки, зоології, географії, хімії, педагогічний кабінет ${ }^{13}$.

I якщо виникають сумніви про існування кафедри фізичного виховання, бо точно відомо, що викладачів цього предмету в навчальному закладі не вистачало, то точно можемо стверджувати про існування інших кафедр, з співзвучними до кабінетів назвами. Підтверджується це у звіті про діяльність інституту вже за 1946-1947 навчальний рік (далі н.р.).

У складі ВНЗ діяло 8 кафедр: основ марксизму-ленінізму; історії; педагогіки; математики; мови і літератури; фізики; природознавства; географії14.

Зі збільшенням кількості викладачів, кафедр і кількості студентів збільшується і кількість спеціалізованих кабінетів у 1947-1948 н.р., а саме: основ марксизмуленінізму, історичний, педагогічний, літератури, математики, фізкультури, геогра$\phi і і ̈$, ботанічний, дарвінізму та хімічний 15 .

Гостра потреба у вчительських кадрах вимагала швидкого налагодження безперебійної роботи педагогічних вищих начальних закладів, належної організації у них навчального процесу, забезпечення його кваліфікованими науково-педагогічними кадрами.

У 1946 р. кафедри інституту були повністю укомплектовані викладачами, 70\% яких працювали тут до війни. Проте, з 33 викладачів, лише 3-є мали науковий ступінь кандидата наук, із них звання доцента - лише 2-є: завідуючих кафедрами - 8; доцентів кафедр - 2; старших викладачів - 7; викладачів - 6; асистентів - $10^{16}$.

Проте, незважаючи на швидке відновлення та зростання викладацького штату після війни, проблема науково-педагогічних кадрів стояла все ще гостро. Перед вищою школою постала нагальна потреба підвищення рівня кваліфікації викладачів $\mathrm{i}$ забезпечення ними, так званих периферійних вузів, до яких відносили й Уманський державний учительський інститут.

Гострий брак кадрів з науковими ступенями та званнями в учительському інституті відчувався ще дуже довго. У 1947 р. не вистачало викладачів таких дисциплін: викладач основ марксизму-ленінізму - 1; доцент кафедри математики (для читання курсу елементарної математики або аналітичної геометрії) - 1 ; доцент кафедри фізики - 1; зав. кафедрою історії, доцент (він же викладач історії СРСР) - 1; викладач

\footnotetext{
11 Архів Музею історії Уманського державного педагогічного університету імені Павла Тичини. Ф. 1. Оп. 1. Спр. 3. Арк. 46.

12 Державний архів Черкаської області (далі - Держархів Черкаської обл.) Ф. Р-1418. Оп. 1. Спр 5. Арк. 36.

13 Держархів Черкаської обл. Ф. Р-1418. Оп. 1. Спр 5. Арк. 2.

14 Держархів Черкаської обл. Ф. Р-1418. Оп. 2. Спр 29. Арк. 14.

15 Держархів Черкаської обл. Ф. Р-1418. Оп. 2. Спр 29. Арк. 14.

16 Центральний державний архів вищих органів влади та управління України (далі - ЦДАВо України). Ф. 166. Оп. 11. Спр. 318. Арк. 8.
} 
історії нового часу - 1; доцент кафедри педагогіки (для читання курсу педагогіки) 1 ; доцент кафедри природознавства - 117.

Динаміку плинності кадрів з науковими ступенями показано у таблиці № 1. 3 наявних даних можна побачити, що за весь досліджуваний період в інституті не було жодного доктора наук.

Таблиця № 1 Динаміка викладачів Уманського державного учительського інституту (1944-1955 pp.)

\begin{tabular}{|c|c|c|c|c|c|c|c|}
\hline $\begin{array}{c}\text { Навчальний } \\
\text { рік }\end{array}$ & $\begin{array}{c}\text { Докторів } \\
\text { наук, про- } \\
\text { фесорів }\end{array}$ & $\begin{array}{c}\text { Кандидатів } \\
\text { наук, доцен- } \\
\text { тів }\end{array}$ & $\begin{array}{c}\text { Кандидатів } \\
\text { наук, без нау- } \\
\text { кового ступе- } \\
\text { ня }\end{array}$ & $\begin{array}{l}\text { Кандидатів } \\
\text { наук, стар- } \\
\text { ших вик- } \\
\text { ладачів }\end{array}$ & 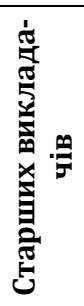 & 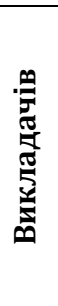 & 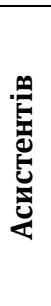 \\
\hline $1944-1945$ & - & 1 & 1 & - & 12 & 8 & 5 \\
\hline 1946-1947 & - & 2 & & - & 7 & 6 & 10 \\
\hline $1947-1948$ & - & 2 & 1 & - & - & 34 & - \\
\hline $1949-1950$ & - & 2 & 1 & - & - & 37 & - \\
\hline 1951-1952 & - & 3 & - & 3 & 14 & 18 & 7 \\
\hline 1954-1955 & - & 5 & 2 & - & 16 & 1 & 4 \\
\hline
\end{tabular}

Забезпечити периферійні вузи молодими науковими кадрами намагалися системою призначення на місця роботи. Таким чином до Умані було направлено у 19451946 н.р. 6 викладачів, 4 молодих спеціалісти, троє з них - Міністерством освіти УРСР. Відомо, що серед них були: викладач історії стародавнього світу Горбач В.М. і викладач української мови та літератури Пентій К.М18. Керівництво інституту було задоволене новоприбулими. За рік роботи вони справились із навантаженням, крім того працювали над підвищенням кваліфікації. У звіті за 1947-1948 н.р. подано характеристики на окремих викладачів, зокрема, на молодих, які почали працювати у попередньому навчальному році. Негативні характеристики відсутні, що наштовхує на сумніви в об’єктивності керівництва або бажання дирекції показати інститут 3 кращого боку. Наприклад, «т. Горбач В.М. - преподает историю древнего мира и средних веков. Растущий преподаватель. Много и настойчиво работает над лекциями. Лекции продуманные, насыщенные фактами, излагаются в четкой и доступной форме. Требовательный к студентам в их знаниях, отчетах в их самостоятельной работе. В преподавательской работе тесно увязывает учебную работу с заданиями воспитания, идеологического роста студентов.

т. Мищенко А.К. - преподаватель русского языка и истории русской литературы. Хорошо владеет предметом, вдумчивый и серьезный в работе. Занятия по языку и литературе правильно построены, изложение материала последовательно, хорошо формулируется.

т. Пентий К.М. - преподает украинский язык, ведет литературный курс истории

17 ЦДАВО України. Ф. 166. Оп. 11. Спр. 318. Арк. 8; Держархів Черкаської обл. Ф. Р-1418. Оп. 2. Спр 14. Арк. 2-3.

18 Держархів Черкаської обл. Ф. Р-1418. Оп. 2. Спр 14. Арк. 2. 
украинской литературы на историческом факультете. Преподавание ведет живо, с интересом; изложение материала эмоционально насыщено; материал живо увязывается с нашей современностью»19.

Попрацювавши в інститут всього рік, викладач Горбач В.М. вже у 1947-1948 н.р. очолив кафедру історії, зайняв посаду секретаря парторганізації та входив до складу Ради інституту20. Згодом займатиме посаду заступника директора з науководослідної роботи та директора інституту.

Пізніше згідно наказу Міністерства вищої освіти СРСР № 795 від 4 червня 1948 р. випускники аспірантури зобов'язані були відпрацювати три роки по путівці міністерств і відомств у підпорядкуванні яких знаходився вуз або науково-дослідна установа ${ }^{21}$.

Відомо, що після Другої світової війни не вистачало якраз кваліфікованих викладачів із досвідом роботи, поширена була робота за сумісництвом. Проте в Уманському учительському інституті все ж переважна більшість викладачів мала досвід роботи у вищих навчальних закладах більше 10 років, що видно з таблиці № 2.

Таблиця № $2^{22}$

Педагогічний стаж викладачів УдУІ

\begin{tabular}{|c|c|c|c|c|c|}
\hline \multirow{2}{*}{$\begin{array}{c}\text { Всього } \\
\text { викладачів }\end{array}$} & \multicolumn{5}{|c|}{ 3 них: } \\
\cline { 2 - 6 } & \multicolumn{5}{|c|}{ За стажем роботи у вищій школі } \\
\cline { 2 - 6 } & до 1 p. & до 3 p. & до 5 p. & до 10 p. & більше 10 p. \\
\hline 33 & 4 & 2 & 5 & 9 & 13 \\
\hline
\end{tabular}

Органи влади в особі різних структурних підрозділів Міністерства освіти УРСР вимагали детальну інформацію про науково-педагогічний склад вищих навчальних закладів. У звітах про діяльність Уманського учительського інституту Міністерству освіти УРСР знаходимо детальну інформацію не лише про стаж роботи викладачів і партійну приналежність, а й про національність, навіть про статус чи місце перебування під час Другої світової війни. У 1946-1947 н.р. до Наркомату освіти надали такі дані: учасників Великої Вітчизняної війни - 13; жили в евакуації - 9; жили на окупаційній території - 11; нагороджених орденами і медалями - $18^{23}$. Такі дані навчальний заклад подавав у звітах Міністерству до 1954 р.

У таблиці № 3 відображено інформацію стосовно викладачів, яку у перше повоєнне десятиріччя вимагав Наркомат освіти (згодом Міністерство освіти) та його підрозділи від Уманського інституту. Аналіз зазначених даних свідчить, що у повоєнний період спостерігається збільшення частки викладачів жіночої статі, а також збільшення частки молодих за віком викладачів, більша частина яких, як правило, не мали вчених ступенів і звань. Серед представників різних національностей найбільшу частку складали викладачі-українці.

19 ЦДАВО України. Ф. 166. Оп. 15. Спр. 468. Арк. 8-9.

20 Держархів Черкаської обл. Ф. Р-1418. Оп. 2. Спр 14. Арк. 9.

${ }^{21}$ Васильчук Т.В. Проблеми відновлення науково-дослідної діяльності вузів УРСР після Великої вітчизняної війни // Грані: Науково-теоретичний і громадсько-політичний альманах. Дніпропетровськ: ДНУ, 2003. № 6 (листопад-грудень). С. 55.

22 ЦДАВО України. Ф. 166. Оп. 11. Спр. 318. Арк. 3.

23 Ibidem. 
Характеристика викладащького складу УдУІ (1944-1955 рр.)

\begin{tabular}{|l|c|c|c|c|c|c|c|}
\hline $\begin{array}{c}\text { Навчальний } \\
\text { рік }\end{array}$ & \multicolumn{2}{|c|}{ За статтю } & \multicolumn{2}{|c|}{ За партійністю } & \multicolumn{2}{c|}{ За національністю } \\
\cline { 2 - 8 } & жін. & чол. & $\begin{array}{c}\text { членів і } \\
\text { кандидатів } \\
\text { ВКП(б), } \\
\text { членів } \\
\text { ВЛКСМ }\end{array}$ & & & & \\
\hline $1944-1946$ & 9 & 18 & - & - & - & - & - \\
\hline $1946-1947$ & 4 & 29 & 14 & 19 & & & \\
\hline $1947-1948$ & 30 & 7 & - & - & - & - & - \\
\hline $1949-1950$ & - & - & 14 & 24 & 4 & 33 & 3 \\
\hline $1951-1952$ & - & - & 17 & 25 & 7 & 33 & 4 \\
\hline $1954-1955$ & - & - & 14 & - & 3 & 22 & 3 \\
\hline
\end{tabular}

У 1946 р. знову відновлює свою роботу історичний факультет (ліквідований у 1935 р.). До діяльності цього факультету та його викладачів, змісту викладання предметів відразу була прикута особлива увага з боку керівництва країни загалом i Наркомату освіти, зокрема, безперечно і керівництва інституту та партійного осередку. Про пильну увагу до викладачів історичного факультету свідчить часта зміна завідувачів кафедри марксизму-ленінізму: 1945 р. Трегуб Н.І., 1946 р. - Товбіс Б.Н., 3 другої половини 1946 р. - Підпригорщук І.В.25. Виходячи з архівної інформації, на завідувачів кафедрою марксизму-ленінізму покладали керівництво ідеологічною сферою не лише в інституті, а й в Умані та районі. Під керівництвом завідувача кафедри марксизму-ленінізму була пропагандистська робота, яку проводили у колгоспах $\mathrm{i}$ селах не лише Уманського, а й сусіднього Христинівського району. I хоча згадані співробітники залишилися працювати на кафедрі, проте, очевидно, не виконали завдань комуністичної партії.

Окремою сферою роботи викладачів інституту було підвищення кваліфікації. У сучасному розумінні підвищення кваліфікації - це удосконалення науковопедагогічними працівниками своєї професійної підготовки, що здійснюється шляхом навчання та стажування у вітчизняних і закордонних вищих навчальних закладах, наукових та освітньо-наукових установах, підприємствах, організаціях, як правило один раз на п'ять років. Проте у радянський період керівництво вищих навчальних закладів розуміло термін «підвищення кваліфікації» дещо інакше - складання кандидатських іспитів, написання та захист дисертацій, робота над ідеологічним рівнем тощо. Так, у звіті про діяльність інституту за 1946-1947 н.р. Уманського учительського інституту вказано, що «истекший год была проведена значительная работа по повышению квалификации преподавателей. Выполняя исторические решения ЦК ВКП(б) и ЦК КП(б)У, в работе на идеологическом фронте, преподаватели лучше готовились к лекциям, больше работали над собой, серьезнее готовились к сда-

${ }^{24}$ ЦДАВО України. Ф. 166. Оп. 11. Спр. 318. Арк. 8; ЦДАВО України. Ф. 166. Оп. 11. Спр. 468. Арк. 8; ЦДАВО України. Ф. 166. Оп. 11. Спр. 836. Арк.7; ЦДАВО України. Ф. 166. Оп. 11. Спр. 318. Арк. 9; ЦДАВО України. Ф. 166. Оп. 15. Спр. 1688. Арк. 5.

25 Держархів Черкаської обл. Ф. Р-1418. Оп. 2. Спр 29. Арк. 67. 
че кандидатского минимума и к защите кандидатских диссертаций. 4 преподавателя (Кравченко Л.М., Онищенко И.Й., Руткевич И.В., Прищенко Э.М.) закончили свои кандидатские диссертации... За истекший учебный год 10 преподавателей сдали кандидатский минимум»26.

Підвищення кваліфікації здійснювалося відповідно до річного плану інституту. До розділу підвищення кваліфікації відносили і підготовку доповідей на конференції та їх проведення. Пізніше, у 1954-1955 н.р. викладачі підвищували свій науковий та ідеологічний рівень, навчаючись у вечірньому університеті марксизмуленінізму27. Наукова робота колективу теж зводилася до підготовки кандидатських дисертацій, публікації журнальних і газетних статей, доповідей на конференції. Підготовка монографій, шкільних і вузівських підручників поки не передбачалася у планах наукової роботи кафедр. Головним завданням викладачів були традиційні для того часу завдання, пов'язані з «вирішенням завдань, які були поставлені в постановах ЦК партії з ідеологічних питань».

Бажання радянської влади контролювати навчання педагогів, пропагандистів, які у майбутньому будуть виховувати дітей у дусі вимог комуністичної моральності та світорозуміння, доходило інколи до абсурду. Так, у звітах про роботу Уманського учительського інституту вміщено не лише зміст лекцій викладачів, а, навіть, зразки відповідей студентів на заняттях та іспитах. 3 1947-1948 н.р. на усіх кафедрах було введено обговорення написаних лекцій і деталізованих конспектів практичних занять. Звітувалися Міністерству і про «Преподавание отдельных предметов» та «Контроль качества преподавания», де детально описувалося теми, методи роботи, самостійна робота студентів, стиль викладання того чи іншого викладача й оцінка його роботи ${ }^{28}$.

Окремим пунктом діяльності інституту було підвищення ідейно-політичного рівня викладачів і контроль трудової та навчальної дисципліни. 3 цією метою діяв марксистсько-ленінський семінар, в якому брав участь увесь науково-педагогічний колектив. Крім того, кожному викладачеві ставилося завдання самостійно вивчати твори класиків марксизму-ленінізму. Щомісяця, інколи двічі на місяць, заслуховувалися доповіді з актуальних питань 29.

Плинність кадрів, звісно, була присутня і пов'язана з вибуттям, переїздом, хворобою, звільненням за власним бажанням. Хоча інститут тримався за кожного викладача, але, наприклад, проти звільнення асистента кафедри педагогіки Польової К.М. не заперечували, тому що «товариш Польова К.М. з читанням курсу не справилась... дуже мало працювала над собою, читала курс поверхнево»30.

У 1949 р. Міністерство вищої освіти СРСР (наказ № 624/ш від 21 червня 1949 р.) для Уманського інституту затвердило штатний розпис - 38 одиниць професорськовикладацького складу 31.

До початку 1949-1950 н.р. навчальний заклад був укомплектований науковопедагогічними кадрами і вакантною залишалася лише посада завідуючого кафедри біології. У зв’язку з цим, викладачі біологічних дисциплін були об’єднані в одну ка-

\footnotetext{
26 Держархів Черкаської обл. Ф. Р-1418. Оп. 2. Спр 14. Арк. 3-6.

27 ЦДАВО України. Ф. 166. Оп. 15. Спр. 1688. Арк. 5.

28 ЦДАВО України. Ф. 166. Оп. 15. Спр. 468. Арк. 17-25.

${ }^{29}$ Ibid. Арк. 12.

30 ЦДАВО України. Ф. 166. Оп. 11. Спр. 836. Арк. 8.

31 Ibid. Арк. 8.
} 
федру - природознавства. В інституті працювали 3 кандидати наук, з них лише один мав вчене звання доцента. Хоча підраховуючи кількість кандидатів наук, сюди включили Руткевича Н.В., чий захист кандидатської дисертації з педагогіки мав лише відбутися, але його (захист - Aвт.) відмінили, тому варто говорити лише про 2-х кандидатів наук ${ }^{32}$.

У зв'язку зі скороченням набору на перший курс інституту на 1952-1953 н.р., було скорочено кількість викладачів на 14 чоловік. Ті, хто залишився, повністю забезпечували виконання всієї навчальної роботи у 1952-1953 н.р.

При скороченні викладацького складу на 1952-1953 н.р. були враховані професійні та політичні якості всіх викладачів. Залишилися на роботі «викладачі більш високої кваліфікації, які систематично працюють над підвищенням своєї кваліфікації, ведуть наукову роботу і повністю забезпечують ідейно-політичне виховання студентів»33. Хоча виходячи із наведених вище даних, залишилися працювати в інституті лише «благонадійні» та «вірні партії» викладачі.

Таким чином, складною проблемою післявоєнного періоду було комплектування педагогічних інститутів УРСР, зокрема, професорсько-викладацькими кадрами. Відповідно, Уманський учительський інститут після Другої світової війни відновив свою роботу, не маючи викладачів певних предметів. Проте на відміну від інших інститутів, мав кваліфіковані кадри, стаж роботи яких у вищій школі більше десяти років. У складних соціально-економічних умовах післявоєнної відбудови вдалось організувати прийом студентів налагодити випуск спеціалістів. Досягнення таких результатів у відновленні підготовки кваліфікованих педагогів було можливим завдяки, головним чином, державній політиці, що включала у цей період цілу систему надзвичайних заходів. Але платою за провідну роль держави у цьому процесі став надмірний ідеологічний тиск та жорсткий контроль за змістом навчання та науково-педагогічними кадрами, які його забезпечували.

\section{REFERENCES}

Chyzhevskyi, B. (2003). Osvita u pisliavoienni roky [Education in the postwar years]. Osvita Ukrainy, 24 chervnia [in Ukrainian].

Lukianenko, 0. (2019). «Naiblyzhchi druzi partii»: kolektyvy pedahohichnykh vyshiv Ukrainy v obrazakh shchodennia 1920-kh - pershoi polovyny 1960-kh rokiv [«The closest friends of the party»: collectives of pedagogical institutes of Ukraine in the images of their everyday of the 1920's - the first half of the 1960's]. Poltava: Vydavnytstvo «Simon» [in Ukrainian].

Maiboroda, V. (1992). Vyshcha pedahohichna osvita v Ukraini: istoriia, dosvid, uroky (1917-1985 rr.) [Higher pedagogical education in Ukraine: history, experience, lessons (1917-1985)]. Kyiv: Lybid [in Ukrainian].

Michuda, V. (2016). Radianska systema osvity u povoiennyi period (1945-1950 roky) [Soviet system of education in the postwar period (1945-1950)]. Molodyi vchenyi, 12.1, 265-271 [in Ukrainian].

Protsyshyn, N. (2013). Dynamika kilkisnoho ta yakisnoho kadrovoho zabezpechennia pedahohichnykh instytutiv Ukrainy 1945-1950 rokiv [Dynamics quantitative and qualitative staffing Pedagogical Institute Ukraine in 1945-1950]. Obrii, 2, 23-24 [in Ukrainian].

Vasylchuk, T. (2003). Problemy vidnovlennia naukovo-doslidnoi diialnosti vuziv URSR pislia Velykoi vitchyznianoi viiny [Problems of Reconstruction of Scientific Researching Activity of Ukrainian High School after Great Patriotic War]. Hrani: Naukovo-teoretychnyi i hromadsko-politychnyi almanakh, 6, 52-56 [in Ukrainian].

Vasylchuk, T. (2003). Vidnovlennia vyshchoi pedahohichnoi osvity Ukrainskoi RSR pislia Velykoi vitchyznianoi viiny [Reconstruction of higher education in Ukrainian SSR after the Great Patriotic

\footnotetext{
32 Ibid. Арк. 9.

33 ЦДАВО України. Ф. 166. Оп. 11. Спр. 1152. Арк. 7.
} 
War]. Naukovi pratsi istorychnoho fakultetu ZDU, XVI, 245-250 [in Ukrainian].

Zuliak, I. (2012). Naukova i navchalno-vykhovna diialnist Kremenetskoho uchytelskoho instytutu v 1940-kh rr. (na osnovi arkhivnykh materialiv) [Research and Training and Educational Activities Kremenets Teacher's Institute in 1940s (based on Archival Material)]. In: Kucherepa, M.M. (Ed.). Volyn i volyniany u Druhii svitovii viini: zbirnyk naukovykh prats, (pp. 197-206). Lutsk [in Ukrainian].

\section{Olena Dzhahunova}

(Pavlo Tychyna Uman State Pedagogical University, Uman, Ukraine)

ORCID: https://orcid.org/0000-0003-2129-9761

\section{Scientific and Pedagogical Staff of Uman Teachers Institute in the Post-War Period (Post-War Years) 1946-1954}

The paper describes the process of reconstruction, development, and activities of Uman State Teachers Institute after the Second World War as well as the state of its provision with the teaching staff and the state policy towards it, in the post-war period.

According to the order of People's Commissar of Education of the Ukrainian SSR P.G. Tychyna, after whom Uman State Pedagogical University is named now, the official resumption of Uman State Teachers Institute activities took place immediately after the German troops had been expelled from the territory of the town. In June 1944, 18 lecturers were employed at both faculties of the Institute (Physics and Mathematics, and Natural Sciences and Geography), and in 1945, there already were 27 lecturers, but there still was the shortage of specialists in physics and physical training. It is the fact that after the Second World War there were not enough qualified lecturers with experience, and the work on a part-time basis was widespread. However, at Uman Teachers Institute, the vast majority of the teaching staff had more than 10 years' experience in higher education.

Particular attention in the paper is paid to the analysis of the dynamics of quantitative and qualitative characteristics of the scientific and pedagogical staff of the Institute. The detailed information not only about lecturers work experience and party affiliation is given, but also about nationality, even status during World War II.

Keywords: Uman Teachers Institute, scientific and pedagogical staff, pedagogical education, post-war period 